\title{
Pemetaan sebaran erosi tanah prediksi melalui integrasi model USLE ke dalam Sistem Informasi Geografis
}

\author{
Spatial mapping of soil erosion prediction through integration USLE model into Geography \\ Information System
}

Sri Malahayati Yusuf ab, Kukuh Murtilaksono ${ }^{\text {a }}$, Dwi Mei Laraswati ${ }^{\mathrm{a}}$

${ }^{a}$ Departemen Ilmu Tanah dan Sumberdaya Lahan, Fakultas Pertanian, Institut Pertanian Bogor, Kampus IPB Darmaga Bogor, 16680 , Indonesia [+62 251-629360]

${ }^{\mathrm{b}}$ Pusat Penelitian Lingkungan Hidup, Lembaga Penelitian dan Pengabdian kepada Masyarakat, Institut Pertanian Bogor, Kampus IPB Darmaga Bogor, 16680, Indonesia [+62 251-8621262]

\section{Article Info:}

Received: 12 - 08 - 2020

Accepted: $07-12-2020$

Keywords:

Geography information system, soil erosion, USLE

Corresponding Author: Sri Malahayati Yusuf Departemen Ilmu Tanah dan Sumberdaya Lahan, Institut Pertanian Bogor;

Tel. +62-251-8629360;

Email:

srimalahayati@apps.ipb.ac.id

\begin{abstract}
The application of USLE model to several watersheds in Indonesia shows the diversity of processes that affect soil erosion. The integration of USLE model into Geography Information System (GIS) is able to provide a spatial distribution of soil erosion classes. This study aims to predict the soil erosion rate in various land cover in Ciesek sub watershed by integrating the USLE model into GIS. Undisturbed and disturbed soil sampling was carried out based on soil map unit, accompanied by observations of soil physic characteristics. Soil erosion prediction was done using the raster calculator with input raster-based data that has a certain spatial resolution. Analysis of the erosion class distribution on various land cover and slope classes was carried out by using the cross tabulation method. The results showed that the very low soil erosion class was dominant in the study location, namely in areas with forest land cover. The highest predicted of soil erosion rate resulted from bare land, followed by moorland and mix gardens. This research results are expected to be used for determining the priority location for soil erosion management.
\end{abstract}

How to cite (CSE Style $8^{\text {th }}$ Edition):

Yusuf SM, Murtilaksono K, Laraswati DM. 2020. Pemetaan sebaran erosi tanah prediksi melalui integrasi model USLE ke dalam Sistem Informasi Geografi. JPSL 10(4): 594-606. http://dx.doi.org/10.29244/jpsl.10.4.594-606.

\section{PENDAHULUAN}

Tanah merupakan bagian dari sumber daya alam dengan fungsi yang berbeda-beda tergantung pada tingkat kepentingan/pemanfaatan (Vink, 1975; Hardjowigeno, 2003). Perbedaan tersebut berimplikasi pada proses pemeliharaan tanah yang dilakukan yang terkadang tidak memperhatikan keseimbangan antara pembentukan dan kehilangan tanah. Ketidakseimbangan tersebut dapat mengakibatkan terjadinya kerusakan tanah yang kemudian menyebabkan berkurangnya kemampuan tanah untuk mendukung pertumbuhan tanaman.

Salah satu penyebab terjadinya kerusakan tanah adalah proses erosi (Arsyad, 2010; Murtilaksono, 2013; Lopez-Garcia et al., 2020). Erosi terjadi karena pukulan butir hujan yang langsung mengenai tanah sehingga tanah terdispersi menjadi bagian-bagian kecil dan ditransportasikan ke tempat lain oleh aliran permukaan (Morgan, 1979; Asdak, 2004; Arsyad, 2010; Napoli et al., 2016). Terangkutnya tanah menyebabkan 
hilangnya tanah lapisan atas yang subur dan mempunyai kandungan bahan organik serta unsur hara yang banyak sehingga produktivitas tanah menurun dan tanah kehilangan kemampuannya dalam mengatur keseimbangan air (Arsyad, 2010; Suryawanshi dan Chandramohan, 2016). Erosi tanah juga memengaruhi siklus hidrologi, degradasi tutupan lahan, dan kehilangan biodiversitas (Lopez-Garcia et al., 2020).

Permasalahan tersebut dapat diatasi dengan membuat suatu perencanaan penggunaan lahan yang memperhitungkan aspek pengendalian erosi tanah yakni penerapan teknik konservasi yang memadai. Kaitannya dengan hal tersebut, maka besarnya erosi tanah dari wilayah yang bersangkutan sangatlah diperlukan. Pengukuran erosi secara langsung membutuhkan biaya tinggi dan waktu yang relatif lama, sehingga penggunaan model untuk memprediksi besarnya erosi tanah merupakan suatu alternatif. Salah satu model yang umum digunakan yaitu model USLE/Universal Soil Loss Equation (Nearing et al., 1994; Lal, 1994; Schmitz dan Tameling, 2000; ICRAFT, 2001; Hardjowigeno, 2003; Vadari et al., 2004; Arsyad, 2010; Fitri, 2011; Lee dan Lin, 2015; Simanjuntak et al., 2017; Liastuti et al., 2018; Alewell et al., 2019) yang dikembangkan oleh Wischmeier dan Smith (1978).

Aplikasi model USLE pada beberapa Daerah Aliran Sungai (DAS) di Indonesia menunjukkan keragaman proses yang memengaruhi terjadinya erosi tanah. Penelitian Anasiru (2015) menunjukkan bahwa terdapat tiga kelas bahaya erosi karena pemanfaatan lahan di Sub DAS Langge, DAS Bolango Gorontalo yaitu ringan, sedang, dan sangat berat. Prediksi erosi tanah di daerah hulu Sub DAS Padang menunjukkan bahwa faktor pengelolaan tanaman merupakan faktor yang paling berpengaruh (Bukhari et al., 2015). Hasil penelitian Fitri (2018) menunjukkan bahwa prediksi erosi tanah tertinggi di DAS Ciliwung Hulu dipengaruhi oleh faktor lereng.

DAS Ciliwung Hulu merupakan salah satu DAS penting di Provinsi Jawa Barat dan DKI Jakarta. Penelitian yang dilakukan oleh Fitri (2018) fokus pada prediksi erosi dari lahan agroforestri yang tersebar di seluruh DAS Ciliwung Hulu, sedangkan Nuraida et al. (2016) memprediksi erosi tanah di DAS Ciliwung Hulu berdasarkan nilai konservasi tinggi untuk aspek pengendalian erosi dan sedimentasi. Kondisi DAS Ciliwung Hulu pada dasarnya dipengaruhi oleh kontribusi setiap sub DAS yang ada di dalamnya. Oleh karena itu, informasi dari sub DAS juga menjadi penting.

Berdasarkan informasi yang telah disampaikan, maka penelitian ini bertujuan untuk memprediksi besarnya erosi tanah pada berbagai tutupan lahan di Sub DAS Ciesek (salah satu sub DAS di DAS Ciliwung Hulu) dengan mengintegrasikan model USLE ke dalam Sistem Informasi Georafis (SIG). Hal ini dilakukan karena SIG merupakan alat yang dapat digunakan untuk mengumpulkan, menyimpan, mentransformasi, serta menyajikan data spasial dari suatu fenomena di permukaan bumi (Wiradisastra, 1998; Prahasta, 2002). Pemanfaatan SIG dalam proses prediksi erosi mampu memperbaiki keakuratan prediksi model dan cakupan area kajian, serta mampu menyajikan hasil secara spasial (Suryawanshi dan Chandramohan, 2016; LopezGarcia et al., 2020). Dengan demikian diharapkan dapat membantu pengambil keputusan untuk merencanakan konservasi tanah dan air pada suatu area.

\section{METODE}

\section{Lokasi dan Waktu Penelitian}

Penelitian dilakukan pada bulan Januari sampai Juni 2019 di Sub DAS Ciesek (Gambar 1). Sifat kimia dan fisika tanah dianalisis di Laboratorium Kimia Tanah, dan Laboratorium Fisika Tanah, Departemen Ilmu Tanah dan Sumberdaya Lahan, IPB. 


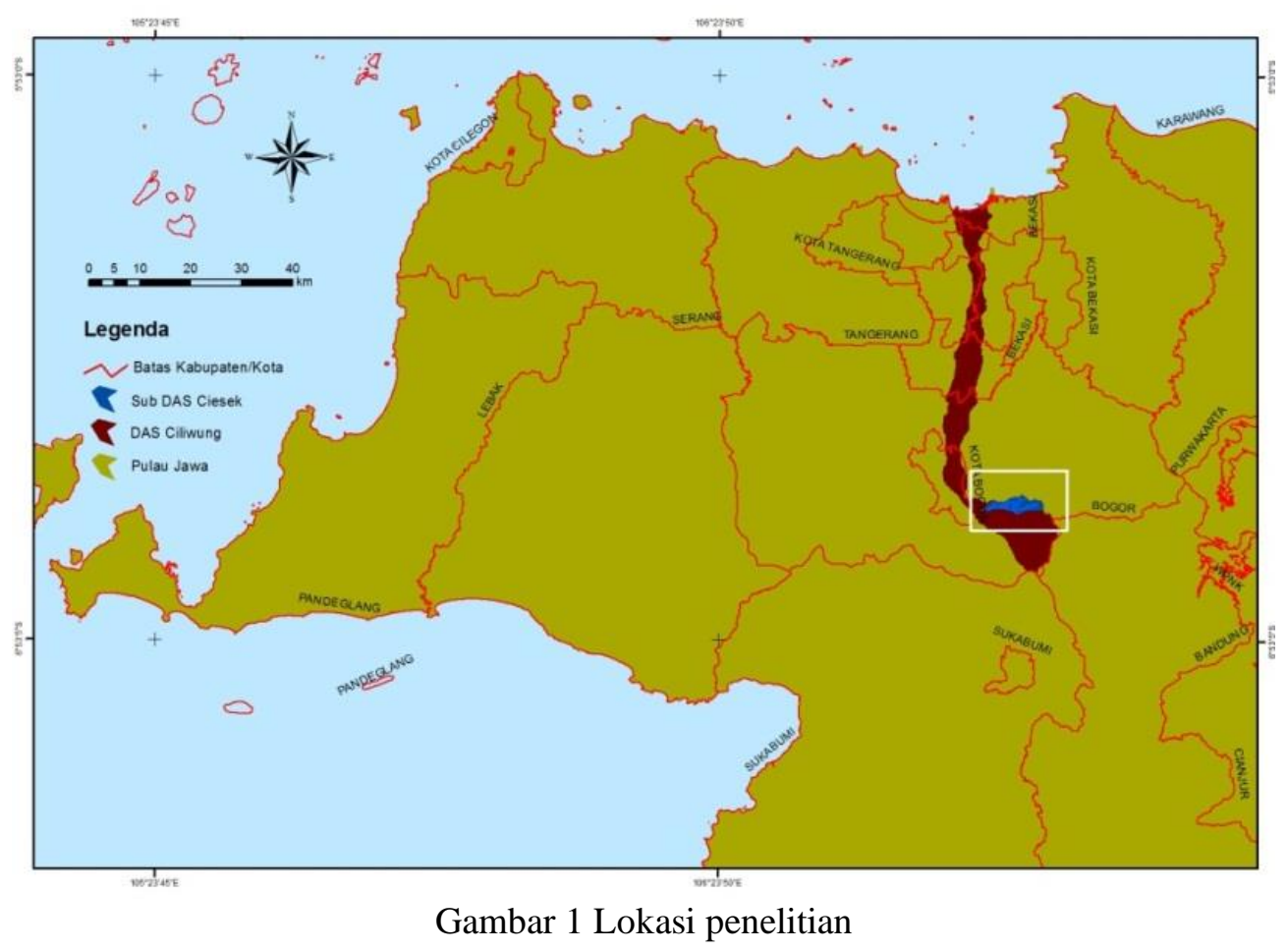

\section{Metode Pengumpulan Data}

Penelitian ini menggunakan dua jenis data yaitu data primer dan data sekunder. Data primer terdiri dari data sifat fisik dan kimia tanah, sedangkan data sekunder meliputi citra tutupan lahan Google Earth, peta jenis tanah, dan data hujan harian, serta nilai erodibilitas tanah di DAS Ciliwung Hulu. Sifat fisik berupa struktur tanah diperoleh dari hasil pengamatan di lapangan, tekstur tanah dianalisis dengan metode pipet, permeabilitas tanah diukur di laboratorium, bobot isi dianalisis dengan metode Black dan Hartge, dan kadar C-organik dengan metode Walkley dan Black. Jenis, sumber, dan kegunaan data disajikan pada Tabel 1.

Tabel 1 Jenis, sumber, dan kegunaan data

\begin{tabular}{|c|c|c|c|}
\hline No & Jenis Data & Sumber Data & Kegunaan Data \\
\hline 1 & Peta Jenis Tanah 1: 50000 & BBSDLP & $\begin{array}{l}\text { Pembuatan peta faktor erodibilitas } \\
\text { tanah, input model USLE-SIG }\end{array}$ \\
\hline 2 & Citra Google Earth & www.GoogleEarth & $\begin{array}{l}\text { Interpretasi jenis tutupan lahan, input } \\
\text { model USLE-SIG }\end{array}$ \\
\hline 3 & DEMNAS & www.tides.big.go.id & $\begin{array}{l}\text { Delineasi batas sub DAS, pembuatan } \\
\text { peta kelas lereng, input model USLE- } \\
\text { SIG }\end{array}$ \\
\hline 4 & Data hujan 2012-2019 & www.bmkg.online & $\begin{array}{l}\text { Perhitungan erosivitas hujan, input } \\
\text { model USLE-SIG }\end{array}$ \\
\hline 5 & Sifat fisik dan kimia tanah & $\begin{array}{l}\text { Hasil analisis } \\
\text { laboratorium dan } \\
\text { pengamatan lapang }\end{array}$ & $\begin{array}{l}\text { Perhitungan faktor erodibilitas tanah, } \\
\text { input model USLE-SIG }\end{array}$ \\
\hline 6 & $\begin{array}{l}\text { Nilai erodibilitas tanah DAS } \\
\text { Ciliwung Hulu* }\end{array}$ & $\begin{array}{l}\text { BPDASHL Citarum } \\
\text { Ciliwung }\end{array}$ & $\begin{array}{l}\text { Melengkapi nilai erodibilitas tanah } \\
\text { untuk jenis tanah di lokasi penelitian } \\
\text { yang belum terwakili oleh pengambilan } \\
\text { sampel tanah }\end{array}$ \\
\hline
\end{tabular}

*BPDASHL Citarum Ciliwung (2016) 
Data primer dalam penelitian ini dihasilkan dari pengamatan secara langsung di Sub DAS Ciesek dan pengambilan sampel tanah dari empat lokasi. Keempat lokasi tersebut ditentukan berdasarkan Satuan Peta Tanah (SPT) Sub DAS Ciesek yang dihasilkan dari tumpangsusun tiga peta yaitu peta tanah, peta tutupan lahan, dan peta lereng. Masing-masing sampel tanah diambil pada kedalaman 0-20 $\mathrm{cm}$ yang terdiri dari 3 ring sampler tanah utuh, dan 1 plastik sampel tanah terganggu (contoh tanah komposit).

\section{Metode Analisis Data}

\section{Delineasi Batas Sub DAS}

Batas Sub DAS Ciesek didelineasi menggunakan data DEMNAS (Digital Elevation Model Nasional) yang dipublikasikan oleh Badan Informasi Geospasial (BIG, 2020). DEMNAS memiliki ukuran sel 8.33 m. Adapun tahapan delineasi yaitu proyeksi koordinat data DEMNAS, fill data DEMNAS, pembentukan arah aliran, akumulasi aliran, dan penentuan titik outlet. Proses fill data DEMNAS dilakukan untuk mengisi data DEMNAS yang kosong sehingga proses pembentukan arah aliran menjadi lebih akurat. Tahap delineasi dilakukan dengan bantuan model hidrologi.

\section{Interpretasi Citra Tutupan Lahan}

Citra tutupan lahan tahun 2019 yang berasal dari Google Earth (2019) diinterpretasi menggunakan metode interpretasi visual. Proses pre-processing citra yang dilakukan adalah koreksi geometrik. Proses interpretasi dilakukan berdasarkan kenampakan jenis tutupan lahan yang ada karena citra Google Earth dapat diinterpretasi pada skala 1: 10 000. Penentuan kenampakan jenis tutupan lahan juga didukung dengan hasil survei tutupan lahan. Selain itu, interpretasi juga dilakukan dengan mengacu pada rona/warna, tekstur, dan pola (Lillesand dan Kiefer, 1997).

\section{Prediksi Erosi Tanah}

Erosi tanah di Sub DAS Ciesek diprediksi menggunakan faktor-faktor yang memengaruhi terjadinya proses erosi tanah yaitu faktor erosivitas hujan, erodibilitas tanah, panjang dan kemiringan lereng, pengelolaan tanaman, dan tindakan konservasi tanah. Keenam faktor tersebut merupakan dasar persamaan USLE (Wischmeier dan Smith, 1978) yang di dalam penelitian ini diintegrasikan ke dalam SIG. Dengan demikian, seluruh informasi penentu erosi tanah seperti data hujan, tanah, tutupan lahan, lereng, dan pengelolaan tindakan konservasi tanah disajikan dalam format raster. Adapun persamaan umum model USLE (Wischmeier dan Smith, 1978) yaitu:

$$
A=R K L S C P
$$

dimana A adalah banyaknya tanah yang tererosi (ton/ha/thn), $\mathrm{R}$ adalah faktor erosivitas hujan (MJ $\mathrm{cm} / \mathrm{ha} / \mathrm{jam}$ ), $\mathrm{K}$ adalah faktor erodibilitas tanah, LS adalah faktor panjang dan kemiringan lereng, dan $\mathrm{CP}$ adalah faktor penutupan vegetasi dan tindakan konservasi tanah. Nilai erosivitas hujan dihitung menggunakan persamaan Bols (1978 di dalam Arsyad, 2010) dengan input parameter curah hujan rata-rata bulanan, jumlah hari hujan, dan curah hujan maksimum selama 24 jam. Data hujan yang digunakan bersumber dari stasiun hujan Citeko periode 2012-2019. Hasil perhitungan disajikan sebagai data atribut peta erosivitas hujan menggunakan platform SIG. Parameter erodibilitas tanah dihitung menggunakan Persamaan Weischmeier dan Smith (1978). Nilai K ditentukan untuk setiap jenis tanah di Sub DAS Ciesek dan digunakan sebagai input atribut untuk peta erodibilitas tanah.

Faktor LS merefleksikan pengaruh panjang (L) dan kemiringan lereng (S) terhadap erosi tanah. Faktor LS di Sub DAS Ciesek ditentukan untuk setiap sel/piksel dengan mengalikan nilai L dan S menggunakan raster calculator dari Spatial Analyst Tools extension. Nilai panjang lereng dihitung dengan persamaan yang telah banyak digunakan pada penelitian sebelumnya (Ma, 2001; Anghel dan Todica, 2008; Bosco et al., 
2009; Tombus et al., 2012; Ganasri dan Ramesh, 2015; Markov dan Nedkov, 2016; Simanjuntak et al., 2017) yaitu:

$$
\text { Panjang lereng }=\text { flow accumulation } x \text { cell size }
$$

Data flow accumulation dibangkitkan dari data DEMNAS, dan ukuran cell size disesuaikan dengan informasi cell size DEMNAS itu sendiri. Flow accumulation merupakan data raster yang berisi informasi akumulasi aliran air terhadap masing-masing sel, yang diperoleh dengan menghitung aliran terakumulasi sebagai bobot/berat terakumulasi dari semua sel yang mengalir ke setiap sel di lereng bawah pada raster output. Input dari tahap ini adalah data arah aliran air. Data raster aliran air berisi arah aliran dari sel dengan nilai tertinggi menuju ke sel dengan nilai terendah. Seluruh proses dilakukan menggunakan menu Hydrology pada Spatial Analyst Tools. Peta kemiringan lereng Sub DAS Ciesek juga diperoleh dari analisis data DEMNAS. Nilai kemiringan lereng (\%) dihitung pada setiap sel menggunakan menu slope pada Spatial Analyst Tools. Kemiringan lereng tersebut dikelompokkan menjadi lima kelas sesuai klasifikasi Departemen Kehutanan (1998).

Nilai pengelolaan tanaman dan tindakan konservasi tanah ditentukan berdasarkan informasi jenis tutupan lahan dan tingkat pengelolaan yang dilakukan di masing-masing lahan. Nilai-nilai tersebut mengacu pada hasil penelitian sebelumnya yang terangkum di dalam Hardjowigeno (2003). Nilai C dan P yang telah ditentukan dijadikan sebagai nilai atribut pada peta CP. Diagram alir prediksi erosi tanah disajikan pada Gambar 2.

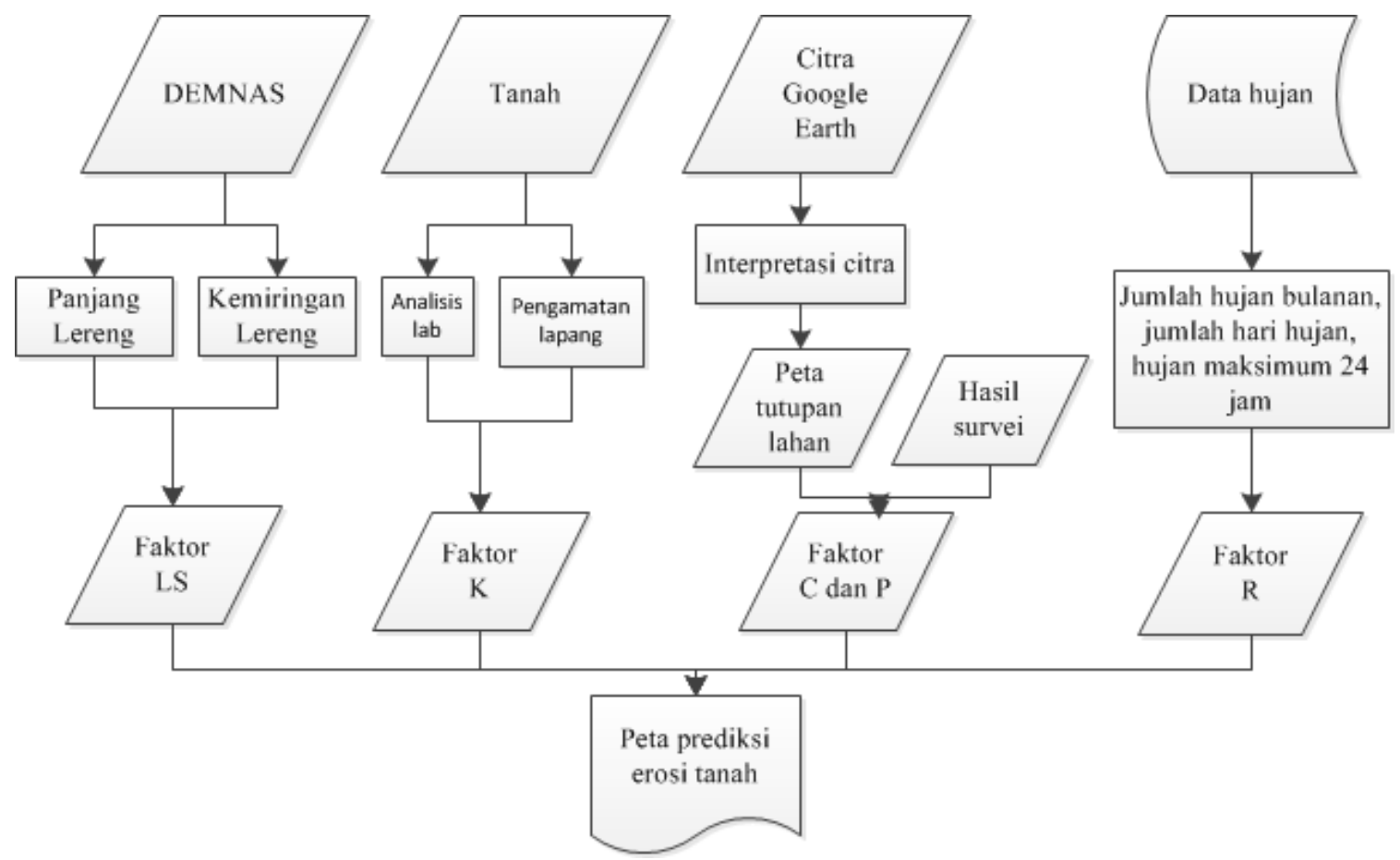

Gambar 2 Diagram alir prediksi erosi tanah

Hasil prediksi erosi tanah dikelompokkan menjadi lima kelas berdasarkan klasifikasi Departemen Kehutanan (1998) untuk mengetahui sebaran spasial kelas tingkat erosi tanah. Nilai prediksi erosi tanah pada masing-masing sel juga dibandingkan dengan nilai erosi yang ditoleransikan (TSL) untuk mengetahui apakah prediksi erosi tersebut melewati batas erosi yang masih dapat ditoleransikan atau tidak. Metode yang digunakan untuk menghitung TSL adalah metode Hammer (1981 dalam Hardjowigeno, 2003). Hal ini dilakukan guna memberikan informasi lengkap kepada stakeholder terkait sehingga hasil yang diperoleh dapat digunakan untuk merencanakan tindakan konservasi tanah yang diperlukan untuk menjamin keberlanjutan fungsi tanah. 


\section{HASIL DAN PEMBAHASAN}

\section{Hasil Delineasi Sub DAS Ciesek}

Delineasi batas Sub DAS Ciesek dilakukan menggunakan data DEMNAS dengan proyeksi UTM 1984. Hasil delineasi menunjukkan bahwa Sub DAS Ciesek memiliki luas sebesar 2428.71 ha. Luas hasil delineasi model ini sedikit berbeda dengan luas Sub DAS Ciesek yang bersumber dari BPDASHL Citarum Ciliwung (2018) yang memiliki luas 2537.25 ha. Perbedaan ini dimungkinkan terjadi karena perbedaan sumber data yang digunakan dalam mendelineasi batas sub DAS. Hasil delineasi Sub DAS Ciesek disajikan pada Gambar 3a.

\section{Tutupan Lahan Sub DAS Ciesek}

Tutupan lahan Sub DAS Ciesek dikelompokkan menjadi enam kelas berdasarkan hasil kenampakan dari citra Google Earth dan juga survei lapang yaitu hutan, kebun campuran, lahan terbuka, pemukiman, sawah, dan tegalan (Tabel 2). Berdasarkan hasil interpretasi, tutupan lahan yang dominan di Sub DAS Ciesek adalah hutan yaitu seluas $48.74 \%$ dari total luas Sub DAS Ciesek. Tutupan lahan dengan luas kedua terbesar adalah kebun campuran sebesar $19.60 \%$, kemudian diikuti oleh tegalan, pemukiman, sawah, dan lahan terbuka dengan luas masing-masing secara berurutan adalah $15.23 \%, 14.47 \%, 1.14 \%$, dan $0.82 \%$ dari total luas Sub DAS Ciesek. Hasil klasifikasi tutupan lahan Sub DAS Ciesek disajikan pada Gambar $3 b$.

Tabel 2 Luas tutupan lahan di Sub DAS Ciesek

\begin{tabular}{clc}
\hline No & Jenis Tutupan Lahan & Luas (ha) \\
\hline 1 & Hutan & 1183.77 \\
2 & Kebun Campuran & 476.00 \\
3 & Lahan Terbuka & 19.86 \\
4 & Pemukiman & 351.53 \\
5 & Sawah & 27.72 \\
6 & Tegalan & 365.81 \\
\hline & Total & 2428.71 \\
\hline
\end{tabular}

\section{Kemiringan Lereng Sub DAS Ciesek}

Daerah studi didominasi oleh kelas lereng agak curam (15-25\%) seluas $25.04 \%$ dari total luas Sub DAS Ciesek, sedangkan kelas lereng terkecil adalah kelas datar (0-8\%) seluas 8.99\% (Tabel 3). Sebaran spasial kelas lereng disajikan pada Gambar 3c.

Tabel 3 Kelas kemiringan lereng di Sub DAS Ciesek

\begin{tabular}{ccc}
\hline No & Kelas Kemiringan Lereng $(\%)$ & Luas (ha) \\
\hline 1 & $0-8$ & 218.43 \\
2 & $8-15$ & 426.39 \\
3 & $15-25$ & 608.18 \\
4 & $25-40$ & 597.75 \\
5 & $>40$ & 577.96 \\
\hline & Total & 2428.71 \\
\hline
\end{tabular}




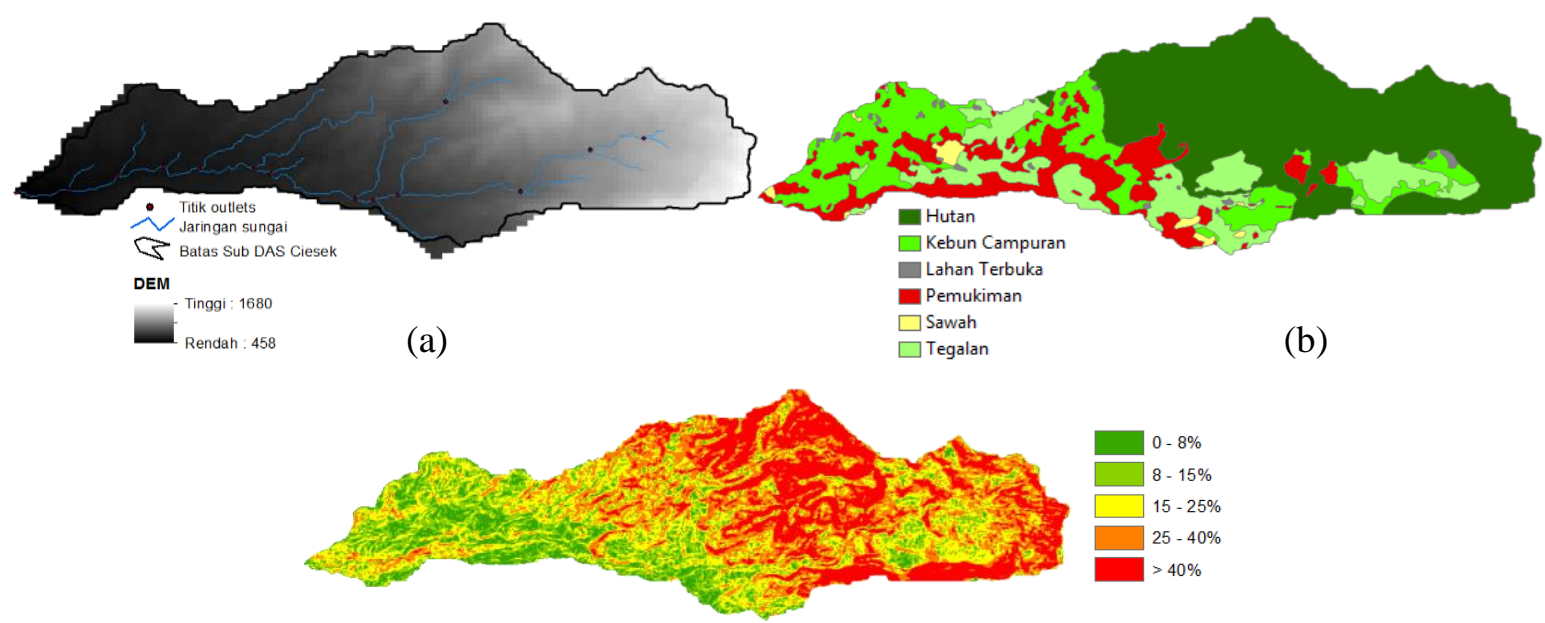

(c)

Gambar 3 Hasil delineasi batas sub DAS (a), hasil interpretasi tutupan lahan (b), dan kelas kemiringan lereng di Sub DAS Ciesek (c)

\section{Prediksi Erosi Tanah}

Nilai dari setiap parameter USLE untuk Sub DAS Ciesek disajikan pada Tabel 4. Nilai erosivitas hujan hanya ada satu nilai yaitu sebesar $3262.78 \mathrm{MJ} \mathrm{cm} / \mathrm{ha} / \mathrm{jam}$. Hal ini dikarenakan data hujan yang digunakan untuk menghitung nilai erosivitas hujan hanya berasal dari satu stasiun hujan saja yaitu Stasiun Klimatologi Citeko dengan periode 2012-2019. Curah hujan maksimum selama periode tersebut tercatat sebesar $630 \mathrm{~mm}$ pada bulan Desember tahun 2012. Jumlah hujan bulanan pada musim penghujan termasuk dalam kategori hujan di atas normal yaitu dengan hujan $>115 \%$ dari rata-rata hujan (klasifikasi hujan berdasarkan BMKG, 2017). Dengan demikian dapat dikatakan bahwa nilai erosivitas hujan di Sub DAS Ciesek termasuk tinggi. Peta faktor erosivitas hujan Sub DAS Ciesek disajikan pada Gambar 4a.

Tabel 4 Nilai-nilai faktor penentu erosi tanah di Sub DAS Ciesek

\begin{tabular}{clc}
\hline No & \multicolumn{1}{c}{ Faktor } & Nilai \\
\hline 1 & Erosivitas hujan (R) & 3262.78 \\
2 & Erodibilitas tanah (K) & $0.11-0.23^{*}$ \\
3 & Panjang dan kemiringan lereng (LS) & $0-6.91^{* *}$ \\
4 & Pengelolaan tanaman dan tindakan konservasi tanah & $0.001-0.9^{* * *}$ \\
\hline
\end{tabular}

Keterangan: *nilai bervariasi untuk setiap jenis tanah dan tutupan lahan, **nilai bervariasi untuk setiap sel, ***nilai bervariasi untuk setiap jenis tutupan lahan

Faktor erodibilitas tanah ditentukan untuk setiap jenis tanah yang ada di dalam Sub DAS Ciesek. Pada poligon jenis tanah yang tidak terwakili oleh pengambilan sampel, maka data erodibilitas tanahnya diisi menggunakan data dari hasil kegiatan BPDASHL Citarum Ciliwung (2016). Faktor erodibilitas tanah ini dipengaruhi juga oleh jenis tutupan lahan yaitu tercermin dari nilai bahan organik yang digunakan dalam perhitung nilai erodibilitas. Oleh karena itu, dalam penentuan nilai erodibilitas dilakukan terlebih dahulu tumpang susun peta tanah dan tutupan lahan. Dengan demikian, satu poligon dengan jenis tanah yang sama bisa memiliki nilai $\mathrm{K}$ yang berbeda apabila jenis tutupan lahannya lebih dari satu. Hal ini dinilai dapat memberikan hasil yang lebih akurat dibandingkan penentuan sebaran spasial nilai $\mathrm{K}$ hanya berdasarkan poligon jenis tanah saja. Nilai erodibilitas tertinggi dihasilkan dari sampel yang berasal dari lahan terbuka dan terendah dari lahan hutan, yaitu masing-masing secara berurutan sebesar 0.23 dan 0.11 (Gambar 4b). Tinggi rendahnya nilai $\mathrm{K}$ dipengaruhi oleh faktor bahan organik, permeabilitas tanah, tekstur dan struktur tanah (Wischmeier dan Smith, 1978; Hardjowigeno, 2003; Arsyad, 2010; Kurnia dan Suwardjo, 1984). 
Sebaran nilai CP di Sub DAS Ciesek adalah 0-0.9 (Gambar 4c). Nilai terendah ditentukan untuk jenis tutupan lahan pemukiman dan sawah, sedangkan nilai tertinggi untuk lahan terbuka. Nilai CP sebesar nol yang ditentukan untuk pemukiman dan sawah dikarenakan kedua jenis tutupan lahan tersebut mampu melindungi permukaan tanah dari pukulan butir hujan dan aliran permukaan. Dengan kata lain, besaran erosi tanah prediksi pada kedua jenis tutupan lahan tersebut tidak akan dianalisis.
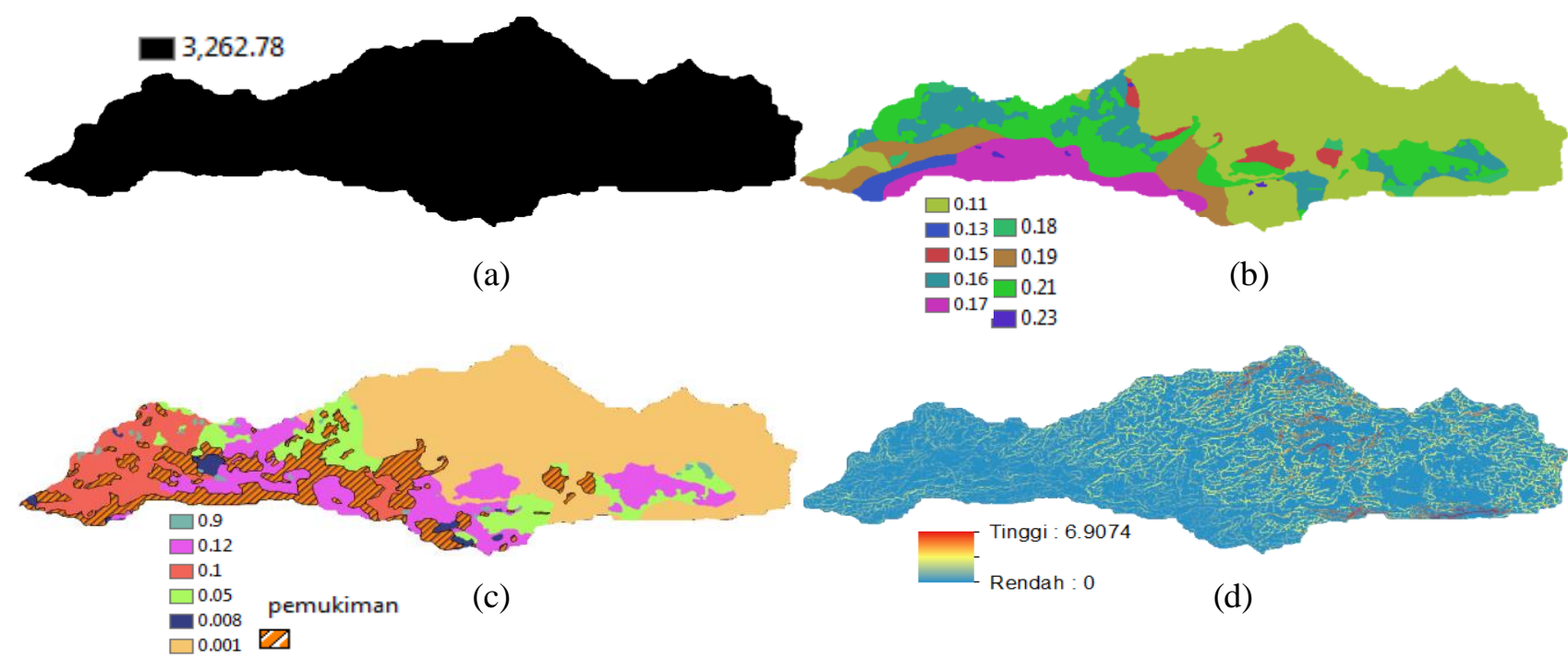

Gambar 4 Sebaran spasial nilai R (a), K (b), CP (c), dan LS (d) di Sub DAS Ciesek

Berdasarkan data panjang dan kemiringan lereng pada tiap sel, maka diperoleh nilai LS dengan kisaran antara 0-6.91. Semakin besar nilai LS berarti semakin panjang dan semakin curam lereng tersebut. Sebaran spasial nilai LS di Sub DAS Ciesek disajikan pada Gambar 4d. Hasil penelitian Simanjuntak et al. (2017) di Sub DAS Kampa menggunakan metode penentuan LS yang sama dengan penelitian ini menunjukkan sebaran nilai LS yang lebih bervariatif yaitu berkisar antara $\leq 0.4$ hingga $>12$. Perbedaan ini tentu saja dikarenakan kondisi alamiah yang berbeda antara kedua lokasi dan juga dipengaruhi oleh perbedaan data DEM yang digunakan dalam penelitian tersebut yaitu DEM SRTM dengan resolusi spasial $30 \mathrm{~m}$.

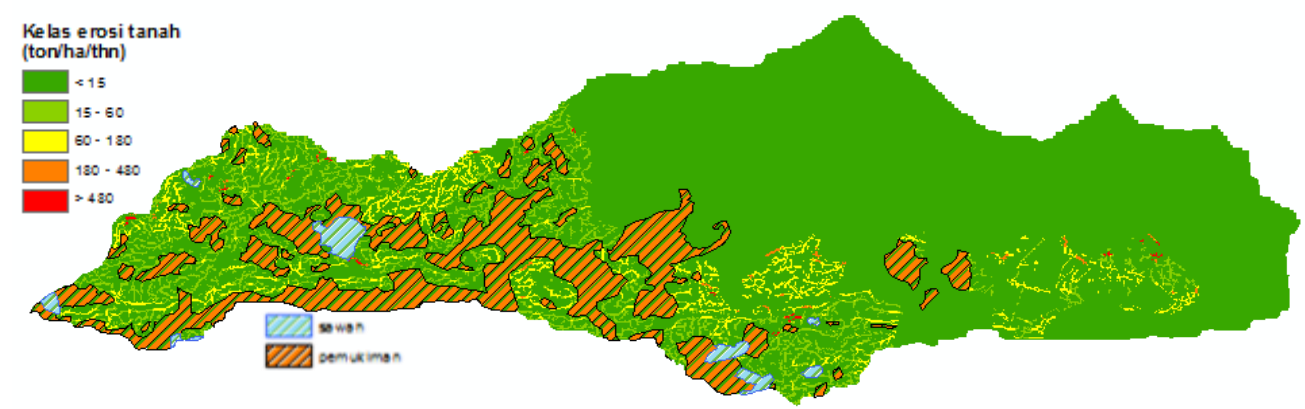

Gambar 5 Sebaran spasial kelas erosi tanah prediksi di Sub DAS Ciesek

Hasil analisis tingkat erosi tanah prediksi di Sub DAS Ciesek disajikan pada Tabel 5, sedangkan sebaran spasialnya disajikan pada Gambar 5. Total luas yang diprediksi tidak sama dengan total luas Sub DAS Ciesek hasil delineasi dikarenakan erosi tanah pada tutupan lahan pemukiman dan sawah tidak diprediksi, sebagaimana telah dijelaskan sebelumnya. Lokasi penelitian didominasi oleh tingkat erosi sangat rendah ( $<15$ ton/ha/thn) yaitu seluas $89.08 \%$ dari total luas sub DAS yang dikaji, sedangkan tingkat erosi yang paling rendah sebarannya adalah kelas sangat tinggi (>480 ton/ha/thn) seluas $0.12 \%$. 
Tabel 5 Klasifikasi kelas tingkat erosi di Sub DAS Ciesek

\begin{tabular}{ccc}
\hline Nilai Kelas & Kelas & Luas (ha) \\
\hline$<15$ & Sangat rendah & 1798.22 \\
$15-60$ & Rendah & 135.83 \\
$60-180$ & Sedang & 78.05 \\
$180-480$ & Tinggi & 4.05 \\
$>480$ & Sangat tinggi & 2.45 \\
\hline & Total & 2018.60 \\
\hline
\end{tabular}

Hasil tabulasi silang antara atribut peta sebaran tingkat kelas erosi dengan peta tutupan lahan menunjukkan bahwa daerah yang memiliki tingkat erosi sangat rendah adalah daerah yang didominasi tutupan hutan, kemudian diikuti oleh jenis tutupan lahan kebun campuran, tegalan dan lahan terbuka dengan luas masing-masing secara berurutan sebesar 1 162.09, 347.69, 273.08, dan 15.36 ha. Selain itu, data tersebut juga ditabulasi silang dengan atribut peta kemiringan lereng sehingga dapat diketahui bahwa sebagian besar erosi tanah prediksi di lahan hutan pada kelas sangat rendah ini terjadi pada kelas lereng sangat curam yaitu sekitar $43.48 \%$ dari total luas kelas erosi sangat rendah di lahan hutan. Tingkat erosi tanah pada kelas sangat rendah di lahan kebun campuran dominan terjadi pada kelas lereng agak curam, sedangkan pada tegalan dan lahan terbuka pada kelas lereng landai dengan persentase masing-masing secara berurutan sebesar 31.86\%, $40.28 \%$, dan $32.74 \%$ dari total luas kelas erosi sangat rendah pada masing-masing tutupan lahan tersebut.

Dominasi nilai prediksi erosi tanah sangat rendah pada lahan hutan dikarenakan sifat hutan yang mampu menjaga tanah dari pukulan butir hujan yaitu dari kombinasi adanya kanopi dan juga serasah di permukaan tanahnya. Hujan yang jatuh akan terlebih dahulu tertahan pada kanopi dan kemudian ada bagian dari hujan tersebut yang akan sampai ke permukaan tanah baik melalui lolosan tajuk/kanopi maupun dari batang. Bagian air hujan yang sampai di permukaan tanah akan tertahan oleh adanya serasah sehingga tanah menjadi terlindungi dari kemungkinan terjadinya proses dispersi. Selain itu, tanah-tanah pada lahan hutan juga memiliki kandungan bahan organik tinggi yang mempunyai fungsi sebagai granulator (Hardjowigeno, 2003).

Sebaran tingkat erosi tanah prediksi pada kelas sangat tinggi dominan terjadi pada lahan terbuka (2.36 ha), kemudian diikuti oleh kebun campuran (0.07 ha), dan tegalan (0.03 ha). Kelas erosi tanah sangat tinggi di lahan terbuka dominan terjadi pada lereng agak curam, kemudian diikuti pada lereng curam, dan sangat curam. Hal ini dikarenakan sebaran lahan terbuka lebih banyak pada lereng agak curam dibandingkan pada lereng curam dan sangat curam. Kebun campuran memiliki sebaran kelas erosi sangat tinggi yang lebih besar dibandingkan lahan tegalan karena kelas erosi tersebut dominan terjadi pada lereng sangat curam, dan pada lereng terebut, masyarakat masih dominan mengusahakan kebun campuran dibandingkan tegalan.

Pada analisis di level sel/piksel, nilai erosi tanah prediksi tertinggi pada kelas sangat tinggi terjadi pada lahan terbuka dengan kemiringan lereng sangat curam yaitu sebesar 1367.04 ton/ha/thn, kemudian diikuti oleh tegalan dan kebun campuran masing-masing secara berurutan sebesar 1172.94 dan 777.24 ton/ha/thn pada kelas lereng sangat curam. Hasil penelitian Bukhari et al. (2015) di hulu Sub DAS Padang juga menunjukkan bahwa prediksi erosi tanah tertinggi terjadi pada lahan terbuka dengan kemiringan lereng yang sangat curam yaitu berkisar antara 2 790.86-7 177.84 ton/ha/thn.

Tingginya nilai prediksi erosi tanah pada lahan terbuka telah sesuai dengan teori dikarenakan tanah tidak terlindungi dari apapun sehingga partikel tanah lebih mudah terdispersi dan didukung oleh kelas lereng yang sangat curam, sehingga kehilangan tanah pada lahan terbuka menjadi lebih banyak dibandingkan pada tutupan lahan lainnya. Hal tersebut dipengaruhi oleh faktor erodibilitas tanah di lahan terbuka yang paling tinggi dibandingkan nilai $\mathrm{K}$ pada lahan lainnya yaitu sebesar 0.23 . Berdasarkan kelas erodibilitas tanah USDA-SCS (1973 dalam Dangler dan El-Swaify, 1976), nilai tersebut masuk dalam kategori kelas sedang yang berarti kepekaan tanah terhadap erosi adalah sedang.

Tanah pada lahan terbuka di lokasi penelitian memiliki kelas tekstur liat dengan kandungan klei sebesar $58.98 \%$. Berdasarkan teori, tanah-tanah dengan tekstur liat cenderung lebih tahan terhadap pukulan butir 602 
hujan dan daya angkut aliran permukaan (Hardjowigeno, 2003; Dariah et al., 2004). Dengan demikian seharusnya prediksi erosi tanah adalah rendah-sedang. Meski demikian, tekstur bukanlah satu-satunya faktor yang memengaruhi erosi tanah. Kombinasi sifat tanah lainnya di lahan terbuka seperti nilai bahan organik yang rendah $(1.85 \%)$, permeabilitas yang masuk dalam kategori lambat, dan struktur yang kurang mantap menyebabkan hasil prediksi kehilangan tanah di lahan terbuka menjadi lebih tinggi. Hasil penelitian Kurnia dan Suwardjo (1984) menunjukkan bahwa nilai erodibilitas tanah akan semakin meningkat pada tanah dengan bahan organik rendah dan struktur kurang baik. Morgan (1979) juga menyatakan bahwa tanah-tanah yang umumnya peka terhadap erosi adalah tanah dengan kandungan bahan organik kurang dari $2 \%$. Dengan demikian agregat tanah menjadi tidak mantap sehingga tidak tahan terhadap pukulan butir hujan dan daya angkut aliran permukaan. Selain itu dipengaruhi pula oleh faktor pengelolaan tanaman dan tindakan konservasi tanah yang mendekati satu di lahan terbuka.

Erosi tanah prediksi pada lahan tegalan dibandingkan kebun campuran pada kelas kemiringan lereng sangat curam lebih tinggi dikarenakan pengolahan tanah di lahan tegalan lebih intensif, termasuk pembersihan gulma dari permukaan lahan sehingga permukaan tanah menjadi lebih terbuka dibandingkan di lahan kebun campuran. Beberapa faktor yang menyebabkan tingginya hasil prediksi erosi tanah di lahan tegalan dibandingkan pada lahan kebun campuran adalah nilai permeabilitas tanah dan bahan organik yang lebih rendah di lahan tegalan yaitu masing-masing secara berurutan sebesar $0.9 \mathrm{~cm} / \mathrm{jam}$ dan $3.72 \%$ dibandingkan di lahan kebun campuran sebesar $4.2 \mathrm{~cm} / \mathrm{jam}$ dan $9.47 \%$. Dengan demikian, faktor K di lahan tegalan lebih tinggi dibandingkan lahan kebun campuran. Nilai permeabilitas yang rendah menyebabkan air tidak mudah meresap ke dalam tanah, sehingga aliran permukaan besar dan potensi terjadinya erosi tanah juga besar (Hardjowigeno, 2003).

Sebaran kelas erosi rendah (15-60 ton/ha/thn) dominan terjadi pada area dengan tutupan lahan kebun campuran (102.18 ha) kemudian diikuti oleh lahan tegalan (33.38 ha) yaitu pada kelas kemiringan lereng agak curam hingga curam. Kejadian sebaliknya terjadi pada kelas erosi sedang dan tinggi, yaitu area dengan tutupan lahan tegalan lebih dominan dibandingkan lahan kebun campuran masing-masing secara berurutan sebesar 52.92 ha dan 2.88 ha dibandingkan 24.82 ha dan 0.11 ha dan dominan terjadi pada kelas lereng agak curam hingga curam. Hal ini menunjukkan bahwa faktor LS dan CP sangat memengaruhi besarnya prediksi erosi tanah. Prediksi erosi tanah semakin tinggi pada jenis tutupan lahan yang sama pada lereng yang semakin curam. Dengan demikian, kombinasi faktor tanah yaitu nilai K, faktor panjang dan kecuraman lereng, serta pengelolaan tanaman dan tindakan konservasi merupakan hal yang tidak dapat dipisahkan dalam mengkaji erosi tanah.

\section{Erosi yang Ditoleransikan (TSL)}

Pada kajian erosi tanah, besarnya nilai erosi yang ditoleransikan (TSL) merupakan suatu hal yang penting juga untuk diketahui. Hal ini dikarenakan nilai TSL mampu memberikan gambaran besarnya erosi tanah yang masih bisa ditoleransikan terjadi pada suatu lahan sehingga produktivitas lahan tetap terjaga secara berkelanjutan (Hardjowigeno, 2003; Arsyad, 2010). Besarnya nilai TSL pada setiap jenis tutupan lahan di Sub DAS Ciesek bervariasi dari 9.05 hingga 37.87 ton/ha/thn (Gambar 6). Nilai TSL terendah dihasilkan dari lahan dengan tutupan hutan dan tertinggi dari lahan terbuka. Rendah tingginya nilai TSL sangat dipengaruhi oleh kedalaman efektif tanah, faktor kedalaman, dan bobot isi. Pada lahan-lahan dengan kedalaman efektif dan faktor kedalaman yang sama, maka tinggi rendahnya nilai TSL tergantung pada nilai bobot isi. Semakin tinggi bobot isi, maka nilai TSL juga akan semakin tinggi. Hal ini merupakan penyebab tingginya nilai TSL di lahan terbuka pada lokasi penelitian.

Nilai prediksi erosi tanah pada semua jenis tutupan lahan yang ada menyebar mulai dari kelas erosi sangat rendah hingga sangat tinggi. Pada tutupan lahan hutan, sebagian besar area yaitu dengan kelas erosi sangat rendah $(<15$ ton/ha/thn) memiliki nilai prediksi erosi tanah yang lebih rendah dari nilai TSL dengan 
luas 1162.38 ha atau $99.97 \%$ dari total lahan hutan, sedangkan sebesar $0.03 \%$ area memiliki nilai prediksi erosi tanah yang lebih besar dari TSL. Hal ini dikarenakan pengaruh faktor panjang dan kemiringan lereng.

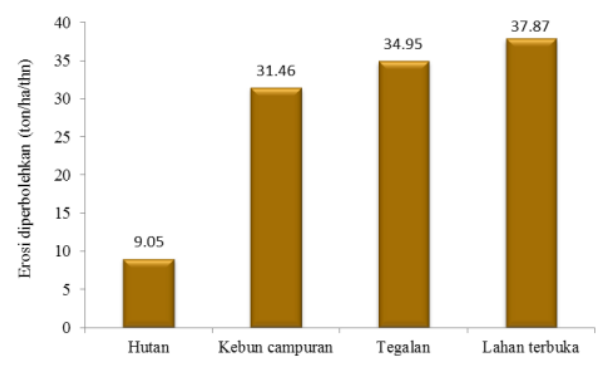

Gambar 6 Besarnya erosi diperbolehkan pada tiap tutupan lahan di Sub DAS Ciesek

Prediksi erosi tanah yang lebih rendah dari nilai TSL di lahan tegalan seluas 289.80 ha yang terdiri dari seluruh kelas erosi sangat rendah $(<15$ ton/ha/thn) dan sebagian dari kelas erosi rendah. Begitu pula untuk lahan kebun campuran dan lahan terbuka, dengan total luas sebaran kelas erosi yang lebih kecil dari TSL adalah 398.87 dan 15.44 ha. Sebaran prediksi erosi tanah di lahan tegalan, kebun campuran, dan lahan terbuka yang lebih besar dari nilai TSL mencakup sebagian kelas erosi rendah, seluruh kelas erosi sedang, tinggi, dan sangat tinggi dengan luasan masinng-masing secara berurutan sebesar 72.51, 76.08, dan 3.63 ha. Dengan demikian, masih terdapat lahan-lahan di lokasi penelitian yang memiliki nilai erosi tanah prediksi lebih besar dari TSL. Hal ini menggambarkan bahwa tingkat pengelolaan lahan yang dilakukan dapat memengaruhi keberlanjutan fungsi atau produktivitas dari lahan itu sendiri. Dengan demikian, pada daerahdaerah dengan nilai prediksi erosi tanah lebih besar dari TSL diperlukan suatu perencanaan teknik pengelolaan tanaman dan tindakan konservasi tanah yang dapat menurunkan nilai erosi tanah sehingga lebih kecil dari nilai TSL. Perencanaan tersebut tentunya dengan tetap memperhatikan keuntungan yang akan diperoleh petani dan aspek keberlanjutan fungsi lahan.

\section{SIMPULAN}

Integrasi model USLE ke dalam Sistem Informasi Geografis pada kajian prediksi erosi tanah di Sub DAS Ciesek mampu menunjukkan sebaran lokasi yang perlu diprioritaskan dalam penanganan masalah erosi tanah di Sub DAS Ciesek. Prioritas utama yaitu pada lahan dengan prediksi erosi tanah tertinggi yang terjadi pada jenis tutupan lahan terbuka, kemudian diikuti oleh tutupan lahan tegalan, dan kebun campuran, pada kelas lereng sangat curam. Sebaran erosi tanah di Sub DAS Ciesek didominasi oleh kelas erosi sangat rendah dan sebagian besar terjadi pada tutupan lahan hutan dengan kelas lereng sangat curam. Sebagian kecil area pada tutupan lahan tegalan, kebun campuran, dan lahan terbuka memiliki nilai prediksi erosi tanah yang lebih besar dari TSL.

\section{UCAPAN TERIMA KASIH}

Ucapan terima kasih disampaikan kepada PPLH IPB yang telah memberikan bantuan dana penelitian melalui skema OGFICE GRANT 2018-2019.

\section{DAFTAR PUSTAKA}

[BIG] Badan Informasi Geospasial. 2020. DEMNAS: Seamless Digital Elevation Model dan Batimetri Nasional [Internet]. [diunduh 2020 Mar 5]. Tersedia pada: http://www.tides.big.go.id.

[BMKG] Badan Meteorologi, Klimatologi, dan Geofisika. 2017. Daftar Istilah Klimatologi. Balai Besar Meteorologi, Klimatologi, dan Geofisika Wilayah III [Internet]. [diunduh pada 2020 Maret 30]. Tersedia pada: http://www.balai3.denpasar.bmkg.go.id. 
[BPDASHL] Balai Pengelolaan Daerah Airan Sungai Citarum Ciliwung. 2016. Aplikasi SWAT untuk Implementasi Rencana Tindak Pengelolaan DAS Citarum, Ciliwung, Cisadane. Bogor (ID): BPDASHL Citarum Ciliwung, Direktorat Jenderal Pengendalian DAS dan Hutan Lindung, Kementerian Lingkungan Hidup dan Kehutanan.

[BPDASHL] Balai Pengelolaan Daerah Aliran Sungai Citarum Ciliwung. 2018. Batas DAS di Wilayah Kerja BPDASHL Citarum Ciliwung. Bogor (ID): BPDASHL Citarum Ciliwung, Direktorat Jenderal Pengendalian DAS dan Hutan Lindung, Kementerian Lingkungan Hidup dan Kehutanan.

[ICRAFT] International Center for Research AgroForestry. 2001. Modelling Erosion at Different Scales, Case Study in the Sumber Jaya Watershed, Lampung, Indonesia. International Report (Unpublished). Bogor (ID): ICRAFT.

Alewell C, Borreli P, Meusburger K, Panagos P. 2019. Using the USLE: Chances, challenges, and limitation of soil erosion. International Soil and Water Conservation Research. 7: 203-225. doi: 10.1016/j.iswcr.2019.05.004.

Anasiru RH. 2015. Perhitungan laju erosi metode USLE untuk pengukuran nilai ekonomi ekologi di Sub DAS Langge, Gorontalo. Jurnal Pengkajian dan Pengembangan Teknologi Pertanian. 18(3): 273-289.

Anghel T, Todica S. 2008. Quantitative assessment of soil erosion using GIS empirical methods. A comparative study between the Motru mining area and the Sucevita catchment. Annals of Oradea University Geography Series. 18: 95-102.

Arsyad S. 2010. Konservasi Tanah dan Air. Bogor (ID): IPB Pr.

Asdak C. 2004. Hidrologi dan Pengelolaan DAS. Yogyakarta (ID): Gajah Mada University Pr.

Bosco C, Rusco E, Montanarella L, Panagos P. 2009. Soil erosion in the Alpine area: risk assessment and climate change. Study Trentini di Scienze Naturali. 85: 117-123.

Bukhari I, Lubis KS, Lubis A. 2015. Pendugaan erosi aktual berdasarkan metode USLE melalui pendekatan vegetasi, kemiringan Lereng, dan erodibilitas di Hulu Sub DAS Padang. Jurnal Online Agroteknologi 3(1): 160-167.

Dariah A, Subagyo H, Tafakresnanto, Marwan S. 2004. Kepekaan tanah terhadap erosi. Jurnal Akta Agrosia. 8: 2-3.

Dangler EW, El-Swaify SA. 1976. Erosion of selected Hawaii soils by simulated rainfall. Soil Sci Soc Am J. 40: 769-773.

Departemen Kehutanan. 1998. Pedoman Penyusunan Rencana Teknik Lapangan dan Konservasi Tanah. Jakarta (ID): Departemen Kehutanan.

Fitri R. 2011. Prediksi erosi pada lahan pertanian di Sub DAS Krueng Simpo Provinsi Aceh. Jurnal Hidrolitan. 2(3): 96-102.

Fitri R. 2018. Prediksi erosi pada lahan petani agroforestri di DAS Ciliwung Hulu, Provinsi Jawa Barat. Jurnal Agrosains dan Teknologi. 3(1): 13-18.

Ganasri BP, Ramesh H. 2015. Assessment of soil erosion by RUSLE model using remote sensing and gis - a case study of Nethravathi basin. Geoscience Frontier. 30: 1-9.

Google Earth. 2019. Citra Tutupan Lahan [Internet]. [diunduh pada 2019 Jan 10]. Tersedia pada: http://www.earth.google.com.

Hardjowigeno S. 2003. Ilmu Tanah. Jakarta (ID): Akademika Pressindo.

Kurnia U, Suwardjo H. 1984. Kepekaan erosi beberapa jenis tanah di Jawa menurut metode USLE. Pembrit Penel Tanah dan Pupuk. 3: 17-20.

Lal R. 1994. Soil erosion by wind and water: problem and prospects. In: Lal R (Ed). Soil Erosion Research Method. Florida (US): Soil and Water Conservation Society.

Lee Ming-Hsi, Lin Huan-Hsuan. 2015. Evaluation of annual rainfall erosivity index based on daily, monthly, and annual precipitation data of rainfall station network in Southern Taiwan. International Journal of Distributed Sensor Networks. 2015: 1-15. doi: 10.1155/2015/214708. 
Liastuti P, Chandra TO, Widiarso B. 2018. Prediksi erosi dengan metode USLE di Perkebunan Kelapa Sawit PTP XIII Gunung Meliau Kecamatan Meliau Kabupaten Sanggau. Jurnal Perkebunan dan Lahan Tropika. 8(2): 67-79. doi: 10.26418/plt.v8i2.29800.

Lillesand TM, Kiefer RW. 1997. Penginderaan Jauh dan Interpretasi Citra. Dulbahri, Suharsono P, Hartono, Suharyadi, penerjemah; Sutanto, editor. Yogyakarta (ID): Fakultas Geografi UGM.

Lopez-Garcia EM, Torres-Trejo E, Lopez-Reyes L, Flores-Dominguez AD, Pena-Moreno RD, Lopez-Olguin JF. 2020. Estimation of soil erosion using USLE and GIS in the locality of Tzicatlacoyan, Puebla, Mexico. Soil and Water Research. 15(1): 9-17. doi: 10.17221/165/2018-SWR.

Ma J. 2001. Combining the USLE and GIS/ArcView for Soil Erosion Estimation in Fall Creek Watershed in Ithaca, New York [Internet]. [diunduh 2008 Feb 15]. Tersedia pada: http://www.ssc.bibalex.org.

Markov B, Nedkov S. 2016. Mapping of erosion regulation ecosystem services. In: Bandrova T, Konecny M, editor. Proceeding of $6^{\text {th }}$ International Conference on Cartography and GIS [Internet]. [2016 June 1317, Albena, Bulgaria]. [diunduh 2020 Mei 3]. Tersedia pada: http://cartography-gis.com.

Morgan RPC. 1979. Soil Erosion and Conservation. $3^{\text {rd }}$ edition. Australia (AU): Blackwell.

Morgan RPC. 1979. Soil Erosion. London (GB): Longmans.

Murtilaksono K. 2013. Penyelarasan Implementasi Pengelolaan Daerah Aliran Sungai di Indonesia. Bogor (ID): Institut Pertanian Bogor.

Napoli M, Cecchi S, Orlandini S, Mugnai G, Zanchi CA. 2016. Simulation of field-measured soil loss in Mediterranean hilly areas (Chianty, Italy) with RUSLE. Catena. 145: 246-256.

Nearing MA, Lane LJ, Lopes VL. 1994. Modelling soil erosion. In: Lal R, editor. Soil Erosion Methods. Florida (US): Soil and Water Conservation Society.

Nuraida, Rachman LM, Baskoro DPT. 2016. Analisis nilai konservasi tinggi aspek pengendali erosi dan sedimentasi (HCV 4.2) di DAS Ciliwung Hulu. Jurnal Pengelolaan Sumberdaya Alam dan Lingkungan. 6(2): 151-159. doi: 10.19081/jpsl.6.2.151.

Prahasta E. 2002. Konsep-konsep Dasar Sistem Informasi Geografi. Bandung (ID): Penerbit Informatika.

Schmitz, Tameling. 2000. Modelling Erosion at Different Scales, A Preliminary Virtual Exploration of Sumber Jaya Watershed. Bogor (ID): ICRAF.

Simanjuntak H, Hendrayanto, Puspaningsih N. 2017. Modifikasi metode perhitungan faktor topografi menggunakan Digital Elevation Model (DEM) dalam menduga erosi. Media Konservasi. 22(3): 242251.

Suryawanshi V, Chandramohan. 2016. Application of GIS in hydrology and estimation of soil erosion using USLE model. International Journal of Science and Research. 2016: 483-488. doi: 10.21275/ART20182128.

Tombus FE, Yuksel M, Sahin M, Ozulu IM, Cosar M. 2012. Technical aspects of spatial information II. Assessment of soil erosion based on the method usle: corum province example [Internet]. [2012 May 6-10; Rome, Italy]. Rome (IT): FIG. [diunduh pada 2020 May 31]. Tersedia pada: http://www.fig.net/resources/proceedings/fig_proceedings/fig2012/papers/ts05e/TS05E_tombus_yuks el_et_al_5848.pdf.

Vadari T, Subagyono K, Sutrisno N. 2004. Model prediksi erosi: prinsip, keunggulan, dan keterbatasan. Di dalam: Kurnia U, Rachman A, Dariah A, editor. Teknologi Konservasi Tanah dan Air pada Lahan Kering Berlereng. Bogor (ID): Departemen Pertanian.

Vink APA. 1975. Land Use in Advancing Agriculture. New York (US): Springer-Verlag.

Wischmeier WH, Smith DD. 1978. Predicting Rainfall Erosion Losses: A Guide to Conservation Planning. Washington DC (US): USDA-SED Agric.

Wiradisastra UP. 1989. Metodologi evaluasi lahan dalam hubungan sistem informasi sumberdaya lahan. Makalah lokakarya Sistem Informasi Sumberdaya Lahan untuk Perencanaan Tata Ruang. 1989 Desember 24-25. Yogyakarta (ID): UGM. 